\title{
Fire resistance evaluation of reinforced concrete floors with fire-retardant coating by calculation and experimental method
}

\author{
Andrii Kovalov ${ }^{1 *}$, Yurii Otrosh ${ }^{2}$, Olha Ostroverkh ${ }^{2}$, Oleksandr Hrushovinchuk ${ }^{3}$, and \\ Oleksandr Savchenko ${ }^{2}$ \\ ${ }^{1}$ Cherkasy Institute of Fire Safety named after Chornobyl Heroes of National University of Civil \\ Protection of Ukraine, 8 Onopriienko Ave., 18034 Cherkasy, Ukraine \\ ${ }^{2}$ National University of Civil Defence of Ukraine, Faculty of Civil Protection, 94 Chernyshevska \\ Ave., 61023 Kharkiv, Ukraine \\ ${ }^{3}$ State Certification Center of the Ukrainian SES, 54 Yevhen Sverstiuk Ave., 02002 Kyiv, Ukraine
}

\begin{abstract}
With the help of a previously developed technique based on the solution of inverse and direct problems of heat conductivity, the fire resistance of a hollow-core reinforced concrete floor with "Neosprei" fireretardant plaster coating was estimated. The thermal and physical characteristics, as well as characteristics of the fire-proof ability of "Neosprei" fire-retardant plaster coating, have been determined. The conclusion has been made on the effectiveness of this coating and on the boundaries of the fire-retardant coatings use to ensure the normed values of the fire resistance degree of hollow-core reinforced concrete floors, including in the mining industry.
\end{abstract}

\section{Introduction}

More than 65.000 fires occur in Ukraine annually, with losses amounting to about 2 billion hrn. Due to the fire hazards impact, from 2.500 to 3.500 people die, and more than 20.000 buildings and structures are destroyed.

Currently, from 30 to $50 \%$ of mine workings in Ukraine are accepted as dangerous for the movement of people. Unsatisfactory fastening condition is one of the main causes of high rate of miners accidents [1,2].

The reliability and safety of mine workings are largely solved by the efficiency of interframe fences (laggings). Despite the large number of their types, only wooden and flat reinforced concrete structures have found wide application in domestic industry. The loadbearing structures of interframe fences such as laggings are usually used in the preparatory mine workings. These laggings may be rigid (reinforced concrete structures), semi-elastic (steel, wooden, polymeric laggings), and elastic (cyclone fencing, rolled glass fibre cloth, etc.).

More rarely, and usually in the main and capital mine workings, a flat reinforced concrete lagging is used, which is a flat plate with rectangular cross-section, made of B15

\footnotetext{
* Corresponding author: kovalev27051980@gmail.com
} 
and B25 grade of concrete, reinforced with a welded mesh of wire with St3 $3-8 \mathrm{~mm}$ in diameter. The average volume of its application does not exceed $20 \%$, and in the mines of the Central region of Donbas $-10-12 \%$. The flat reinforced concrete lagging has several disadvantages: large weight (up to $24 \mathrm{~kg}$ ), non-fixed positions of reinforcement cage, the lack of reinforcement which takes up the forces during transportation and setting up.

However, the insufficient load-carrying capacity (breakage of the lagging occurs at a load of $10-15 \mathrm{kPa}$ ) and a short service life (less than $0.5-3$ years as a result of wood rotting in the mine environment) are the causes for mass lagging failures in the form of a brittle fracture with superlimiting deformations. This leads to the rockfall between the support frames in the mine workings, underground workers injuries, accidents at the mine transport, and other negative consequences.

A great deal of those used in modern building constructions, including in the mining industry, are hollow-core reinforced concrete floors of different types. Since the hollowcore reinforced concrete floors have restricted fire resistance, it is actual to ensure their fire protection and increase the fire resistance degree with the use of various substances and materials. One way to improve fire resistance of such structures is the use of fire-retardant plaster compositions of large thickness.

\section{The research problem setting}

The results of research on the fire resistance of both building structures with fire-retardant coatings and without them, as well as the calculation of nonstationary heat conductivity are represented in the works [3, 4] of such scientists as Roitman M.Ya., Fomin S.L., Romanenko P.N., Demchyna B.G., Krukovskyi P.G., Shmukler V.S., Givliud M.M., Novak S.V., Dovbysh A.V., Kovaliov A.I., Bartelemi B., Segerlind L.J., Huebner K.N., Zeinkiewicz O.C., and others. Today, however, without consideration of these researchers are the questions on the identification of the mutual interaction between the parameters of fire-retardant plaster coating and the fire resistance degree of hollow-core reinforced concrete floor, as well as the conditions for the fire protection efficiency increase of reinforced concrete building structures with the use of fire-retardant plaster coatings. Theoretically, this question was studied in [5], but the presented results were in need of experimental verification.

Therefore, the use of a scientific approach to determine the fire-proof ability of "Neosprei" fire-retardant plaster coating, scientific substantiation of the thermal and physical characteristics, and characteristics of the fire-proof ability of this coating under the influence of high temperatures in case of fire is an actual scientific and technical task. This conditioned this work, the decision of which will positively affect the fire safety requirements assurance for the construction, reconstruction, replanning of facilities for various purposes.

The objective of this work is to identify the mutual interaction between the parameters of "Neosprei" fire-retardant plaster coating and the fire-proof ability of the hollow-core reinforced concrete floor, as a scientific basis for their use in construction with account of fire safety requirements.

\section{Materials and methods used to study the fire resistance of hollow-core reinforced concrete floors}

Today in Ukraine, to determine the fire resistance degree of any reinforced concrete structure (columns, beams, floors, coatings, partition walls) with a fire-retardant coating (cladding) of a certain thickness, it is necessary to conduct each time a fire-resistance test. For example, for floors the tests are carried out according to DSTU B V.1.1-20:2007 "Fire 
protection. Floors and coatings. Method of test for fire resistance", for columns - DSTU B V.1.1-14:2007 "Fire protection. Columns. Method of test for fire resistance". This is done in order to ensure that the chosen thickness value of the fire-retardant coating (cladding) will provide the normed value of the fire resistance degree. Such an approach requires that the structure should be tested for fire resistance if it is necessary to determine the fire resistance with a different value of the fire-retardant coating thickness. It requires significant material and financial costs, because each structure with different values of the fire-retardant coating thickness and the concrete protective layer must be tested to determine the fire resistance degree.

Therefore, in this study, a computational and experimental method will be applied which uses the solution of direct and inverse heat conductivity problems [6-9]. Appropriate methods allow to determine the thermal and physical characteristics (TPC) of fire-retardant materials containing and not containing water, as well as the thermal and physical properties of materials which can sprout. In these methods the models of nonlinear nonstationary heat conductivity are used in one- and two-dimensional setting. At the same time, the methods have been developed not only for heat conductivity determination, but also heat capacity as a function of temperature. These methods have the flexibility and versatility of computational methods and, at the same time, the laboratory experimental methods performance raises the reliability of the calculation.

The computational and experimental method (CEM) is defined as a set of experimental and calculation procedures, which make it possible to determine the necessary characteristics of the studied object, in particular, the dependence of the coating thickness on the thickness of the concrete protective layer. As it was noted above, the CEM is sufficiently effective and accurate method in comparison with an experiment or calculation methods.

\section{The fire resistance test results of reinforced concrete floors with fire-retardant plaster composition}

The determination of the fire resistance of reinforced concrete floors was carried out according to $[10,11]$ until one of the normed for floors boundary conditions in fire resistance states occurred on the grounds of loss of integrity, load-carrying capacity or thermal insulating capacity. The method consisted in the time interval determination from the start of the test under the standard temperature condition, according to [10], of the floors samples (hereinafter - samples) with the fire impact on the sample from below.

Two samples of the PK 48-12-8 hollow-core reinforced concrete floor were put to test. The samples of floors from below and on the sides were covered with a layer of "Neosprei" composition, fire-retardant coating (plaster), with the average total thickness of $25.9 \mathrm{~mm}$. It was performed with the use of a plastering machine "M-tec DUOMIX".

Before to apply the substance, the lower surface of the floors was cleaned with a metal brush and treated with a "Fenix Contact" primer, diluted 1:6 with water. The prime compound flow was $200-300 \mathrm{~g} / \mathrm{m}^{2}$.

The PK 48-12-8 hollow-core reinforced concrete floor with sizes $4780 \times 1190 \mathrm{~mm}$ and width $220 \mathrm{~mm}$. The floor has a carrying steel frame, which consists of five lower longitudinal bearing bars of $12 \mathrm{~mm}$ (the bearing bar grade is not specified) and BP1 reinforcement wire of $4 \mathrm{~mm}$. Concrete B15. The average value of thickness of the concrete protective layer till the lower bearing bar is $20 \mathrm{~mm}$. The fire resistance degree of the floor, according to the manufacturer, is REI 45.

The samples were set on a horizontal furnace (according to order, a statically indeterminate support scheme) with support at the edges through compensating supports made of basalt plates with a thickness of $40 \mathrm{~mm}$. 
The application of loading was performed with calibrated loads in the form of concrete blocks installed on the samples through compensating supports. The actual loading on the samples is set, based on the creation in the plates of stresses, which corresponds to stresses from the specific distribution load of $570 \mathrm{~kg} / \mathrm{m}^{2}$ (Fig. 1).

$a$

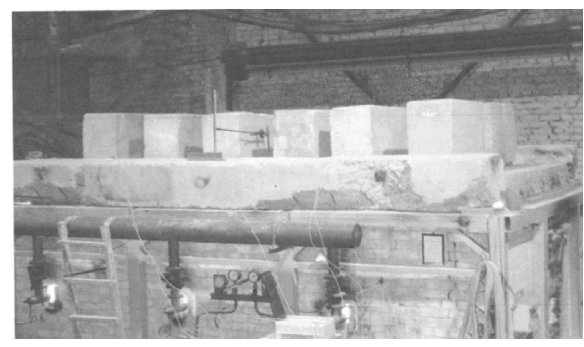

$b$

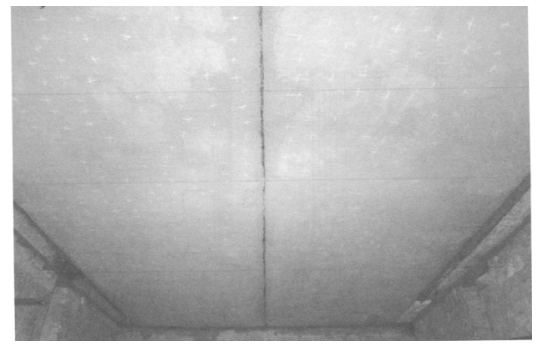

Fig. 1. The view of floors before testing (a) and samples from the furnace side before testing (b).

The deflection limit value of the samples is $220 \mathrm{~mm}$ (run $b=4400 \mathrm{~mm}$, effective thickness of floors is $220 \mathrm{~mm}$ ), and the boundary value of the deformation increase rate $9.8 \mathrm{~mm} / \mathrm{min}$.

To measure the average and maximum temperature from the unheated surface of each sample, 5 thermocouples (T1 - T5) were set: one thermocouple (T1) was set in the center of the sample and four in the geometric centers of quarters of the sample (Fig. 2).
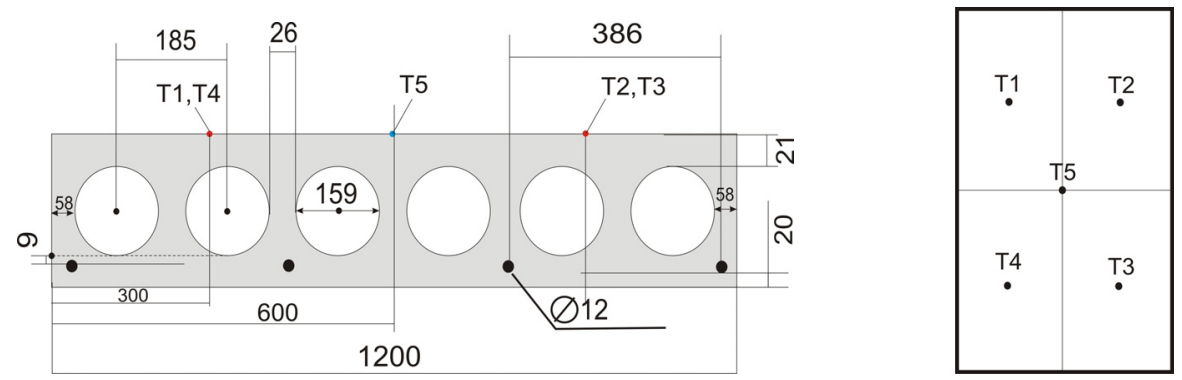

Fig. 2. The scheme of thermocouples placing from the unheated surface of reinforced concrete floor.

Test conditions: air temperature $12^{\circ} \mathrm{C}$, relative air humidity $62 \%$. A horizontal test furnace was used for the tests. The results of temperature measurements in the fired furnace are shown in Fig. 3. The temperatures resulted from the tests for fire resistance of reinforced concrete floors with a fire-retardant coating were subsequently used in determination of the thermal and physical characteristics of concrete, "Neosprei" fireretardant plaster coating. They also were used to determine the dependence of the coating thickness on the thickness of the concrete protective layer for different degrees of fire resistance of the hollow-core reinforced concrete floors (Fig. 4).

The temperature and pressure in the furnace were complied with requirements regulated in accordance with the standard. The excess pressure in the furnace at the 5 th minute was $8 \mathrm{~Pa}$, and starting from the 10th minute $-12 \mathrm{~Pa}$. According to order, tests lasted $242 \mathrm{~min}$. The deflection value and the deformation increase rate of the samples after $242 \mathrm{~min}$ of tests were $42 \mathrm{~mm}$ and $0.4 \mathrm{~mm} / \mathrm{min}$ (sample No. 1), respectively, and $46 \mathrm{~mm}$ and $0.4 \mathrm{~mm} / \mathrm{min}$ (sample №2), respectively. During the tests, there were no losses of integrity, thermal 
insulating capacity, and load-carrying capacity of both samples. The test accuracy during testing was $0.42 \mathrm{~min}$. As a result of fire resistance tests, it is established that the fire resistance degree of the above mentioned floor, covered from below with "Neosprei" fireretardant substance with a thickness of $25.9 \mathrm{~mm}$, is not less than $242 \mathrm{~min}$ (fire-resistance rating - REI 240).

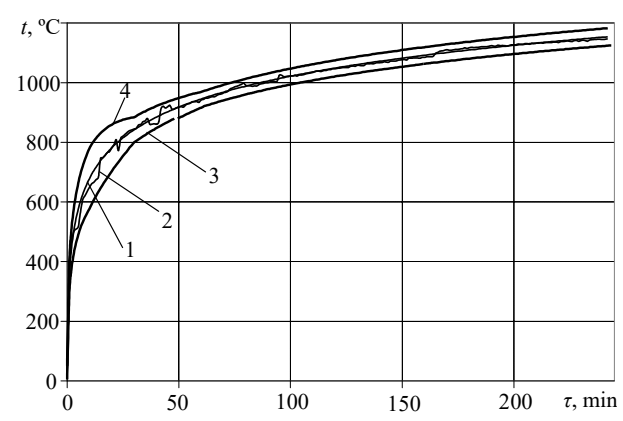

Fig. 3. Dependence of the temperature in the furnace on the time of fire impact on the heated surface of a hollow-core reinforced concrete floor with a thickness of $220 \mathrm{~mm}$, treated with a plaster composition: curve 1 -standard temperature condition curve; curve 2-real curve of temperature variation in the furnace; $3-$ permissible minimum temperature values in the furnace in the process of testing; 4 - permissible maximum temperature values in the furnace in the process of testing.

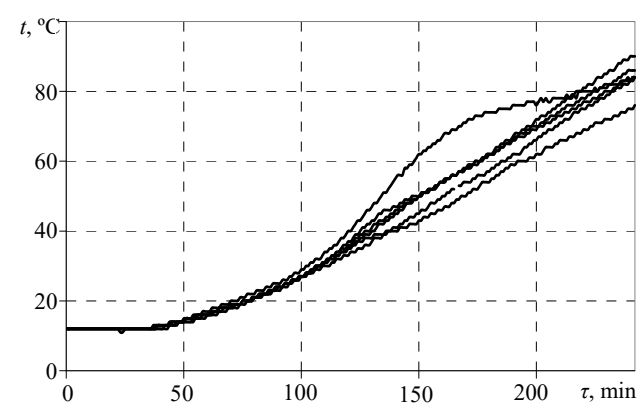

Fig. 4. Dependence of the temperature on the time of fire impact on the unheated surface of a hollow-core reinforced concrete floor with "Neosprei" plaster coating in different places of temperature measurement.

\section{The research results of fire resistance of floors and fire-proof ability of coatings}

To simulate the thermal state of the floor (see Fig. 1), a physical and computer models were developed. The physical model includes an equation system and boundary conditions, which consider the heat conductivity in the coating and concrete, as well as the complex convective-radiative heat exchange in the air cavities (see Fig. 5).

The mathematical model of the heat conductivity process in such a system in the Cartesian coordinate system, which describes the discussed above physical model, has been repeatedly studied in the literature [12]. It is a one-dimensional heat conductivity equation with a combination of radiant heat exchange and boundary conditions of the third kind on the heated surface, boundary conditions of the third kind on the unheated surface which consider the environment temperature. The mathematical model of such a model of the thermal state of the floor consisted of equations that describe the heat conductivity in a sixlayered floor. The second layer in it takes into account natural convection and radiant heat exchange in the cavities by means of effective heat conductivity determined by the solution of inverse heat conductivity problems (IHCP).

The thermal and physical characteristics (TPC) of 1, 3 and 5 concrete layers were assigned from [13], and the thermal and physical characteristics of 2 layer with cavities were found out by solving IHCP (see Fig. 6). The specified thicknesses for 1, 3 and 5 layers for concrete were calculated, and the 2 concrete layer with cavities was chosen as equal to the diameter of the cavities with the available concrete volume. 
$a$

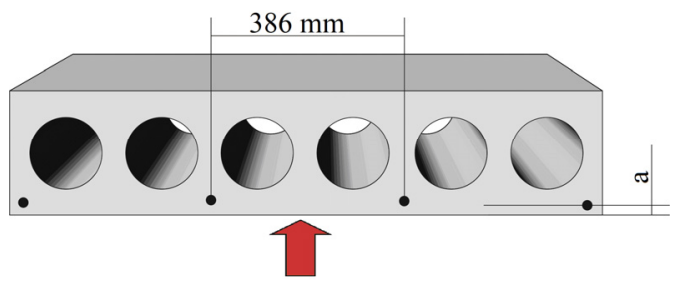

$b$

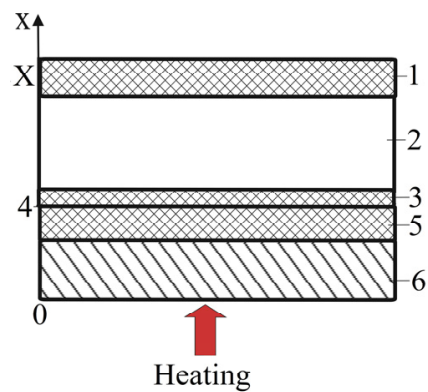

Fig. 5. General view of reinforced concrete floor without fire-retardant coating (a) and the scheme of reinforced concrete floor in a one-dimensional setting (b): 1 - a continuous concrete layer of the floor between the unheated surface and a layer with cavities, 2 - a layer with cavities, 3 - a continuous concrete layer between the cavities and reinforcement, 4 - reinforcement layer, 5 - a continuous concrete layer from the reinforcement till the heated surface, 6 - plaster coating.

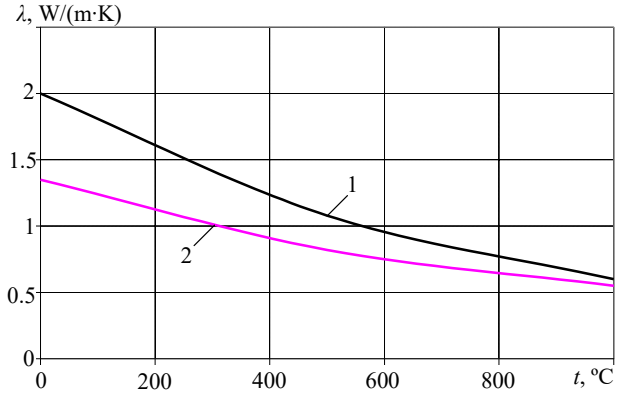

Fig. 6. Coefficient of heat conductivity for concrete: 1 - upper bound; 2 - lower bound.

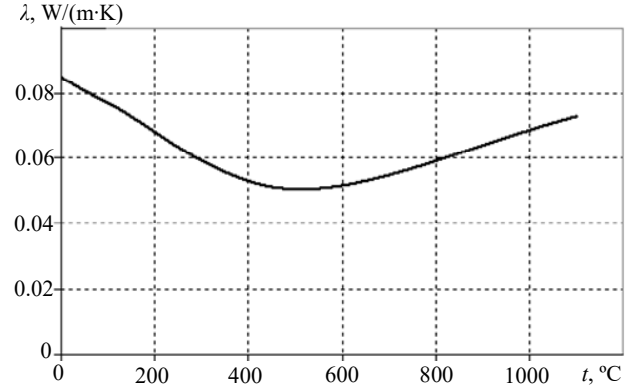

Fig. 7. Dependence of effective heat conductivity coefficient of "Neosprei" plaster coating on the temperature, determined by means of IHCP according to the fire resistance test data.

Specific heat capacity $c_{p}(\theta)$ of dry concrete $(u=0 \%)$ is determined as [8]:

$$
\begin{array}{ll}
c_{p}(\theta)=900(\mathrm{~J} / \mathrm{kg} \cdot \mathrm{K}) & 20{ }^{\circ} \mathrm{C} \leq \theta \leq 100{ }^{\circ} \mathrm{C} ; \\
c_{p}(\theta)=900+(\theta-100)(\mathrm{J} / \mathrm{kg} \cdot \mathrm{K}) & 100^{\circ} \mathrm{C}<\theta \leq 200^{\circ} \mathrm{C} ; \\
c_{p}(\theta)=1000+(\theta-200) / 2(\mathrm{~J} / \mathrm{kg} \cdot \mathrm{K}) & 200^{\circ} \mathrm{C}<\theta \leq 400^{\circ} \mathrm{C} ; \\
c_{p}(\theta)=1100(\mathrm{~J} / \mathrm{kg} \cdot \mathrm{K}) & 400^{\circ} \mathrm{C}<\theta \leq 1200^{\circ} \mathrm{C} .
\end{array}
$$

To determine the TPC of concrete, the computer program FRIEND was used. With its help, it is possible to determine the TPC of fire-retardant coatings of metal, reinforced concrete structures, and other parameters of heat exchange processes from the data of unsteady temperature measurements inside or on the surface of samples.

When determining the thermal and physical characteristics of concrete, as a rule, the method of the inverse heat conductivity problems solution is used. According to this method the determination of the heat conductivity and heat capacity is carried out by comparing the experimental temperatures with the calculated ones.

The criterion for the proximity of these characteristics, most often, is the value: 


$$
F(P)=\sqrt{\frac{\left[\sum_{j=1}^{m}\left(T_{M, j}-T_{\dot{Y}, j}\right)^{2}\right]}{m}} \approx \delta,
$$

where $m$ is the number of experimental measurements used to solve the inverse problem; $\delta$ is the mean square error of measurement.

The heat conductivity coefficient of the layer with cavities was calculated as a constant value. The heat conductivity coefficient of 2 layer with cavities was calculated as constant and equal to $5 \mathrm{~W} / \mathrm{m} \cdot \mathrm{K}$. At the same time, the coefficient of heat transfer from an unheated surface was set according to this law:

\begin{tabular}{|c|c|}
\hline$T, \mathrm{sec}$ & $\alpha_{c 2}, \mathrm{~W} /\left(\mathrm{m}^{2} \cdot \mathrm{K}\right)$ \\
\hline 0 & 0 \\
\hline 1500 & 5 \\
\hline 3600 & 65 \\
\hline
\end{tabular}

The companies-producers of the fire-proof products often indicate the TPC of the developed plaster coatings as a value which does not change with time, that is, it is constant (the heat conductivity in the dry state is $0.11 \mathrm{~W} / \mathrm{m} \cdot \mathrm{K}$ at $20^{\circ} \mathrm{C}$ ). However, in fact, the TPC of plaster compositions, especially those compositions containing water, vary with temperature. Therefore, within the scope of this work, a determination was made of the heat conductivity coefficient of "Neosprei" plaster composition (see Fig. 7) which depends on the temperature. "Neosprei" fire-retardant plaster coating (hereinafter coating) is a nonflammable, thermal insulating system based on exfoliated vermiculite, inorganic binders, fillers and target additives. For this purpose, the temperatures were used from the unheated surface of hollow-core reinforced concrete floor with fire protection.

As it can be seen from Fig. 7, in the temperature range from 0 to $500{ }^{\circ} \mathrm{C}$ ), the value of the heat conductivity coefficient of "Neosprei" plaster coating falls and passes through the minimum value of $0.05 \mathrm{~W} / \mathrm{m} \cdot \mathrm{K}$ (at a temperature of $500{ }^{\circ} \mathrm{C}$ ). This is due to a decrease in density and an increase in the porosity of the coating due to removal of natural and chemically bonding moisture. The increase in the heat conductivity coefficient within the temperature range from 500 to $1100{ }^{\circ} \mathrm{C}$ may be explained by the occurrence of the radiation component in the pores of the coating in combination with its high-temperature shrinkage.

When the TPC of a coating has been determined, the specific heat capacity of the plaster coating was defined as constant and equal to $C_{v}=1 \cdot 10^{6} \mathrm{~J} / \mathrm{m}^{3} \cdot \mathrm{K}$.

To assess and predict the fire resistance of hollow-core reinforced concrete floors with fire-retardant coatings, it is necessary to know the thickness of the fire-retardant plaster coating which provides the normed fire resistance degree of this floor. For this purpose, the characteristics found above are used: TPC of concrete, "Neosprei" plaster coating.

In [14], the fire-proof ability of the reinforced concrete floor coating is defined as the dependence of the fire-retardant coating thickness (see Fig. 8) on the thickness of concrete protective layer (the distance between the heated surface and the adjacent reinforcement). At the same time, the normed fire resistance degree of reinforced concrete floor is provided for boundary conditions of fire resistance on the basis of the thermal insulating capacity loss or achieving a critical temperature by the reinforcement with a load level given in the test [15].

With the obtained characteristics, it is possible to determine the thickness of "Neosprei" fire-retardant plaster coating, depending on the concrete protective layer thickness for the required fire resistance of the structure. In such a case, there happens the boundary condition in the fire resistance of construction on the basis of the achieving a critical 
temperature by the reinforcement at a given load level or thermal insulating capacity of the floor, treated with a fire-proof plaster composition.

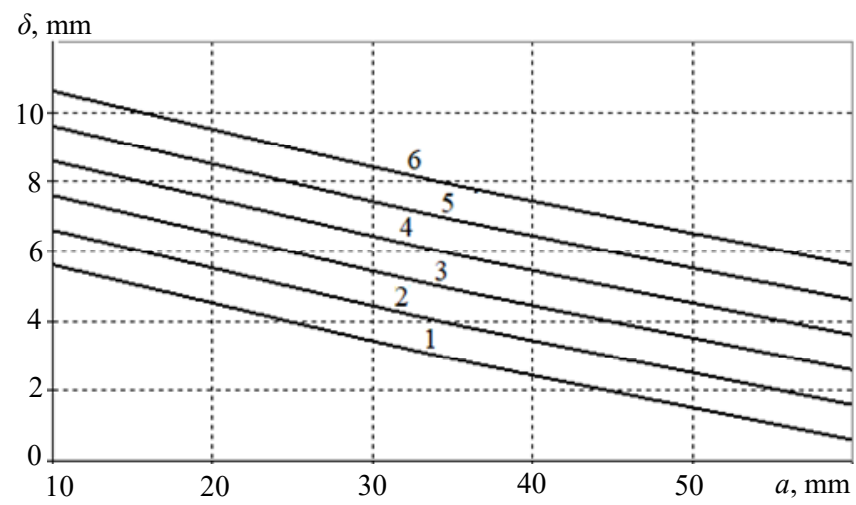

Fig. 8. Dependence of "Neosprey" plaster coating thickness $(\delta)$ on the thickness of concrete protective layer $(a)$ of the hollow-core reinforced concrete floor according to the criterion of achieving a critical temperature $\left(500^{\circ} \mathrm{C}\right)$ by the reinforcement for the fire resistance degree: $1-60 \mathrm{~min} ; 2-90 \mathrm{~min}$; 3 - $120 \mathrm{~min} ; 4-150 \mathrm{~min} ; 5$ - $180 \mathrm{~min} ; 6-240 \mathrm{~min}$.

It should be noted that the accuracy of the fire-proof ability determination is estimated at $16 \%$ and can be higher if additional temperature measurements are used not only on the unheated surface, but also on the reinforcement under the fire-retardant coating and inside the floor.

The advantage of the presented work is the use of computational and experimental method for assessing the fire resistance of structures and fire-proof ability of coatings. This method, if compared with the experimental or calculated, is more economical and allows to evaluate the fire-proof ability of coatings and the fire resistance of structures based on the results of one or several experiments (fire tests), by the use of mathematical models. The obtained results will allow a more accurate approach to the assessment of the fire resistance of structures with fire protection in the design of buildings and structures. The studies will be useful for designers, manufacturers of fire-retardant substances, since they allow to calculate such thicknesses of coatings which could provide a normed fire resistance degree of the structure with a given thickness of the concrete protective layer.

\section{Conclusions}

There was performed an analysis of tests for fire resistance of hollow-core reinforced concrete floors, covered with "Neosprei" plaster composition, manufactured by A PLUS B UKRAINE "PTK", LLC. As a result, it has been established that the fire resistance degree of the PK 48-12-8 hollow-core reinforced concrete floor, covered from below with fireretardant substance with the thickness of $25.9 \mathrm{~mm}$, consisting of "Neosprei" fire-retardant coating (plaster), is not less than 242 min (fire-resistance rating - REI 240). The test results show the possibility of such structures using in the mining industry with the necessary substantiation of their parameters.

The parameters are substantiated and the effectiveness of "Neosprei" fire-retardant plaster coating is proved. The dependence has been established of the heat conductivity coefficient on the temperature in the conditions of heating in the test furnace of the hollow-core reinforced concrete floor with this coating under the standard temperature condition of a fire. 
The mutual interaction has been revealed between the thickness of "Neosprei" fireretardant plaster coating and the fire resistance of the hollow-core reinforced concrete floors. The necessary minimum thicknesses of such a coating have been calculated to provide the fire resistance degrees of $60,90,120,150,180$ and 240 minutes, regulated by the fire safety requirements.

The authors convey sincere thanks for the help and advice during working on this article to Viktor Rivchachenko, Vice Director of PROMAT UKRAINE, TOV.

\section{References}

1. Vivcharenko, O. (2012). Development of coal industry of Ukraine in the context of contemporary challenges. Geomechanical Processes During Underground Mining: School of Underground Mining 2012, 1-5. https://doi.org/10.1201/b13157-2

2. Pivnyak, G.G., Pilov, P.I., Bondarenko, V.I., Surgai, N.S., Tulub, S.B. (2005). Development of coal industry: The part of the power strategy in the Ukraine. Gornyi Zhurnal, (5), 14-17.

3. Roytman, V.N. (2001). Inzhenerne resheniya po otsenke ognestoykosti proyektiruyemykh $i$ rekonstruiruyemykh zdaniy. Moskva: Assotsiatsiya "Pozharnaya bezopasnost' i nauka".

4. Fomin, S.L., \& Astakhov, A.A. (2010). Ognestoykost' fragmenta bezrigel'nogo karkasnogo monolitnogo zdaniya. Naukovyi visnyk budivnytstva, (61), 122-130.

5. Vasil'chenko, A.V. (2010). Otsenka predela ognestoykosti zhelezobetonnykh plit perekrytiya s ognezashchitnym pokrytiem. Problemy pozharnoy bezopasnosti, (27), 45-48.

6. Rubini. P. (2000). SOFIE - Simulation of Fires in Enclosures. V 3.0 Users guide. School of Mechanical Engineering, Granfield University (UK).

7. Bek Dzh., V., Blakuell, B., \& Sent-Kler, Ch. (1989). Nekorrektnye obratnye zadachi teploprovodnosti. Moskva: Mir.

8. Lie, T.T. (1974). Characteristic temperature curves for various fire severities. Fire Tachnol, 10(4), 315-326.

9. Krukovsky, P. (2005). Fire Safety Analysis for new Safe confinement's Building Constructions of Chernobyl NPP. In $V$ Międzunarodova Konferencja "Bezpieczeństwo pożarowe budowli" (pp. 223-227). Warszawa: Instytut Techniki Budowlanej.

10. DSTU B V.1.1-4-98. (1999). Zakhyst vid pozhezhi. Budivelni konstruktsii. Metody vyprobuvannia na vohnestiykist. Zahalni vymohy. Kyiv: Ukrarkhbudinform.

11. DSTU B V.1.1-20:2007. (2007). Zakhyst vid pozhezhi. Perekryttia ta pokryttia. Metod vyprobuvannia na vohnestiikist. Kyiv: Ministerstvo rehionalnoho rozvytku ta budivnytstva Ukrainy.

12. Kovalov, A.I., Kachkar, Ye.V, \& Zobenko, N.V. (2014). Eksperymentalne doslidzhennia vohnezakhysnoi zdatnosti pokryttia "Amotherm Steel Wb" pry temperaturnomu rezhymovi vuhlevodnevoi pozhezhi. Pozhezhna bezpeka: teoriia i praktyka, (17), 53-60.

13. EN 1992-1-2: 2004. (2004). Eurocode 2: Design of concrete structures. Part 1-2: General rules. Structural fire design. Brussels: The European Union Per Regulation.

14. Kovalev, A.I. (2012). Usovershenstvovanie metoda otsenki ognezashchitnoy sposobnosti pokrytiy zhelezobetonnykh perekrytiy. Ph.D. Ukrainskiy NII grazhdanskoy zashchity MChS Ukrainy.

15. Sundstrom, B. (2005). Test Methods and Their use for Fire Safety Engineering. In $V$ Międzunarodova Konferencja "Bezpieczeństwo pożarowe budowli” (pp. 141-150). Warszawa: Instytut Techniki Budowlanej. 